\title{
Обеспечение применения международных договоров в соответствии с конституцией Республики Узбекистан
}

\author{
Умарахунов И.M.*
}

«Строительство открытого демократического государства, формирование рыночных отношений осушествляется на международно-признанной конституционной и правовой базе, обеспечивающей сильные юридические гарантии и условия для реформирования экономики, широкого ее интегрирования в мировое сообщество»'

Суверенитет и независимость каждого государства как субъекта международных отношений обеспечивается нормами национального и международного права. Ст. 17 Конституции Республики Узбекистан имеет большое значение для прогрессивного развития правовой системы нашего государства ${ }^{2}$. Конституция недвусмысленно огдает предпочтение международным правилам, высказываясь за их прямое и непосредственное применение при рассмотрении различных дел. Если возникает «несоответствие» между нормой международного права и нормой внутригосударственного права, то вопрос о том, какую норму

' Умарахунов Иркин М. - к.ю.н., заместитель директора Института философии и права им. И.М. Муминова Академии наук Республики Узбекистан.

' Каринов И.А. Узбекистан на пороге XXI века: угрозы безопасности, условия и гарантии прогресса // По пути безопасности и стабильного развития. Т. 6. Т.: Узбекистон, 1998. С. 212.; см. также: Каримов И.А. Узбекистан: национальная независимость, экономика, политика, идеология. Т.: Узбекистон, 1996. Т. 1. С. 118. Президент И.А. Каримов отмечает, что «ни одно государство не может стать подлинно суверенным, не закрепив в своем Основном Законе принципы государственного и общественного строя, прав и свобод граждан, экономические основы и стратегические направления развития общества».

${ }^{2}$ Конституция Узбекистана развивает принципиальные положения Конституционного закона «Об основах государственной независимости Республики Узбекистан» от 31 августа 1991 года, где международное право определяется как важный источник суверенного государственного строительства. Тем самым Узбекистан на конституционном уровне продемонстрировал мировому сообществу свою приверженность общепризнанным принципам и нормам международного права. Комментарий к Конституции Республики Узбекистан. Т.: Узбекистон, 2001. С. 77. 
следует применять, должен решаться в пользу нормы международного права ${ }^{3}$.

Как подчеркивает Президент Республики Узбекистан И.А. Каримов, «в Конституции отмечено, что Узбекистан является полноправным субъектом международных отношений. Республика превращается в активного члена международных организаций, идет по пути гармоничного вхождения в систему мирового хозяйствования, устанавливает взаимовыгодные отношения с другими странами. Учитывая высшие интересы нашего народа, в Конституции Узбекистана предусматривается возможность создания им различных союзов, его вхождения в содружества и другие межгосударственные структуры» ${ }^{4}$.

Это означает, что примат в Узбекистане международно-правовых норм над внутригосударственными является основополагающим конституционным принципом 5 .

${ }^{3}$ На основе анализа принципов, содержащихся в ст. 17 Конституции, в параграфе сделаны следующие выводы. Во-первых, включение указанных принципов в текст Конституции в значительной степени усиливает внешнеполитический потенциал страны. Во-вторых, последовательная внешнеполитическая практика реализации данных принципов обеспечивает вхождение Республики Узбекистан в систему международных отношений. В-третьих, это интеграция в мирохозяйственные связи, в глобальную и региональные системы коллективной безопасности, что в свою очередь облегчает выполнение основных внутренних задач общественного развития и реализации национальных интересов во внешней политике. В-четвертых, это также формирование имиджа открытой миролюбивой страны, готовой к позитивному международному сотрудничеству со всеми странами мира. В отношении отсылочной формулировки «иных общепризнанных принципов и норм международного права» отмечается, что они имеют такую же силу, как и упомянутые раздельно, открытым текстом принципы. Ничто не указывает на особую иерархию их построения. Если в первом случае речь шла только о принципах, то во втором случае речь идет также и о нормах, то есть о более широком диапазоне источников. Отмечается и то, что в юридической науке до сих пор четко не решен вопрос о том, что есть «обшепризнанные принципы и нормы международного права». Нет единого международного правового акта, где был бы указан перечень этих принципов и норм. Также нет единого мнения у специалистов (А.Н. Талалаев, В.А. Толстик, Ю.М. Колосов и Э.С. Кривчикова, И.И. Лукашук и др.). Турсунов А.С. Конституционные основы внешней политики Республики Узбекистан. Автореферат дис. ... д-ра юрид. наук. Т.: АГОС, 2002. С. 24.; см. также: Турсунов A.C. Узбекистон Республикаси Конституциясида халкаро хукукий муаммоларнинг ифодалниши. / «Узбекистон Республикаси Конституциясини хаётга тадбик килиш муаммолари» халкаро илмий анжуман материаллари. Т.: Узбекистон, 1995. С. 133-135.

${ }^{4}$ Каримюв И.А. Наша цель: свободная и процветаюшая Родина. Т. 2. Т.: Узбекистон, 1996. С. 99.

${ }^{5}$ С.м.: Саидова Л.A. Источники современного дипломатического права: международные договоры и национальное законодательство Республики Узбекистан. Т.: Адолат, 2001. С. 33 . 
Конечно, это не означает, что с введением конституционного положения о примате международного права над внутригосударственным все проблемы тут же сами собой разрешаются.

Примат права означает, что и законодательные органы должны подчиняться тем законам, которые они сами приняли. Это важное обстоятельство, особенно в отношении парламента, который в своей законодательной деятельности связан пределами, установленными конституцией. Достаточно сказать, что примат права предполагает, что в государстве власть в обшественной сфере должна осушествляться при полном уважении соответствуюших законов. Это означает, что все, включая главу государства, парламент, судебные и другие ветви власти, обязаны соблюдать конституцию государства и должны действовать в предписанных ею пределах ${ }^{6}$. Более того, применять данную норму на практике не всегда просто. Следует рассматривать проблему с использованием сравнительно-правового анализа источников национального права, суверенного Узбекистана, которые выступают основным императивом в деле построения активной международной жизни. В этой связи следует обратить внимание на главу III «Верховенство Конституции и Закона» Конституции Республики Узбекистан 1992 г., (ст. 15)7: «В Республике Узбекистан признается безусловное верховенство Конституции и законов Республики Узбекистан. Государство, его органы, должностные лица, общественные объединения, граждане действуют в соответствии с Конституцией и законами»".

Правовую систему любого государства нельзя рассматривать вне связи с другими национальными правовыми системами и международным правом. Такой правовой треугольник служит общим правовым пространством, на котором взаимодействуют, сталкиваются, сосуществуют разные нормативные правовые системы.

${ }^{6}$ Корелл Ханс. Примат международного права и мандат Организации Объединенных Наций // Московский журнал международного права. № 2. 2001. С. 4.

${ }^{7}$ Одним из основных показателей демократического правового государства является равенство всех граждан перед законом, обеспечение верховенства Конституции и законов. Верховенство Конституции и Закона означает: во-первых, господство закона во всех сферах обшественной жизни. Никто, никакой государственный орган, должностное лицо, предприниматель или любой другой гражданин не имеет право быть освобожденным от ответственности перед законом; во-вторых, верховенство Конституции и закона отражает то, что основные социальные, экономнческие и политические отношения регламентируются только законом, а их участники без каких-либо исключений привлекаются к ответственности за нарушение норм права. См.: Комментарий к Конституции Республики Узбекистан. Т.: Адолат, 1997. С. 60.

${ }^{8}$ Конституция Республики Узбекистан. Т.: Адолат, 1999. С. 90. 
Д.ю.н., профессор А.Х. Саидов отмечает, что Конституция Узбекистана 1992 г., отведя международному праву важное место в правовой системе (ст. 17), обусловила тесное соприкосновение Конституционного суда Республики Узбекистан с международным правом. Речь идет о том, что, согласно ст. 109 Конституции Республики Узбекистан, Конституционный суд страны определяет соответствие Конституции межгосударственным договорам

Общепризнанные принципы и нормы международного права в практике Конституционного суда выступают как важные критерии конституционности оспариваемых в Суде законов и иных нормативных актов, подпадающих под его юрисдикцию ${ }^{10}$. Международные нормы лишь тогда могут содействовать развитию сотрудничества между государствами и укреплению мира, когда добросовестно и в полном объеме выполняются договаривающимися сторонами. Международное право представляет собой то поле международного сотрудничества для государства, где последующее содержание этих отношений должно находить осуществление через нормы национального (внутригосударственного) права.

Несмотря на все многообразие, современные конституции обнаруживают множащееся число общих моментов. Взаимозависимость государств требует, чтобы социально-экономические и политические правовые системы государств были совместимы как друг с другом, так и с международной системой ${ }^{1 !}$. Они должны строиться как части

${ }^{9}$ Си.: Абдумажидов $Г$. «Конституционный суд Республики Узбекистан», в серии «Служба защиты прав человека в Узбекистане». Центр по изучению прав человека и гуманитарного права. Т., 1998.; Принципы уголовного судопроизводства и права человека / Материалы международной конференции. Т., 1998.

${ }^{10}$ См.: Саидов A.X. Сравнительное правоведение. Т.: Адолат, 1999. С. 473-474.; см. также: Саидов A.X., Шмидm O., Витрук $H$. Права человека и порядок в государстве начинаются с Конституции // Нар. слово. 1993. 30 дек.; Туляганов А.A. Узбекистон Республикаси Конституцияси ва инсон хукуклари хамда эркинликлари химоя килиш масалалари / Халкаро илмий анжуман материаллари. Т.: Узбекистон, 1995. С. 55-56.; Туляганов A.A. Узбек давлатчилигинг шаклланиш муаммолари / И.А. Каримовнинг “Узбекистон сиёсий-ижтиомий ва иктисодий истикболининг асосий тамойиллари» рисоласи буйича илмий амалий анжуман материаллари. Т., 1995. С. 2001.; Туляганов A.A. Конституциявий конунийлик - ички ишлар органлари фаолиятининг асосидир / Конституция: иктисодий ва хукукий ислохотларни чукурлаштириш муаммолари. Конституциянинг уч йиллигига багишланган илмий амалий анжуман материаллари. Т., 1995. С. 23-24.

11 Для послевоенных конституций характерна тенденция к расширению сферы регулирования внешнеполитической деятельности государства. Это относится прежде всего 
единого международного сообщества с тем, чтобы быть пригодными для широкого взаимодействия с ним во имя мирного сосуществования каждого государства и сообщества в целом.

По мере роста числа общих интересов возрастает значение общечеловеческих ценностей, лежащих в основе международного права. Государство и право - главные составные части механизма регулирования взаимодействия страны с внешней средой. Рост роли международных отношений и их влияния на жизнь национальных обществ ведет к тому, что национальные правовые системы строятся с учетом требований внешней среды и международного права ${ }^{12}$. Международная правоспособность заключать соглашения государствами юридически закрепляется не только в международных нормах, но также и в Основных Законах.

Законодательная практика Республики Узбекистан, которая обеспечивает признание и верховенство норм и принципов международного права в национальном праве ${ }^{13}$, выступает одним из таких примеров.

к официальному провозглашению некоторых принципов внешней политики, регулированию вопросов, связанных с объявлением войны и заключением мира, с соотношением международного и внутригосударственного права, определением полномочий органов государства по заключению, ратификации и денонсации международных договоров, установлением правил, определяющих сотрудничество в области защиты прав человека - гражданство, права и свободы человека, экстрадиция (выдача лица иностранному лицу) и право убежища, регламентацией межгосударственной экономической и военно-политической интеграции. См.: Комментарий к Конституции Республики Узбекистан. Т.: Адолат, 1997. С. 63.

${ }^{12} \mathrm{C}_{M}$.: Indiana Journal of Global Legal Studies. 1994. Vol.1. Issue 2.

${ }^{13} \mathrm{C}$. также: Закон Республики Узбекистан от 14 декабря 2000 г. «О нормативно-правовых актах» (извлечение). Статья 7. «Верховенство Конституции и законов Республики Узбекистан»: В Республике Узбекистан признается безусловное верховенство Конституции и законов Республики Узбекистан. Конституция Республики Узбекистан имеет высшую юридическую силу и применяется на всей территории Республики Узбекистан. Законы и иные нормативно-правовые акты в Республике Узбекистан принимаются на основе и во исполнение Конституции Республики Узбекистан и не могут противоречить ее нормам и принципам. Для сравнительно-правового анализа можно отметить также Конституции Казахстана и Грузии: Конституция Республики Казахстан, от 30 августа 1995 г. (извлечение). Статья 4. 1) Действующим правом в Республике Казахстан являются нормы Конституции, соответствующих ей законов, иных нормативных правовых актов, международных договорных и иных обязательств Республики, а также нормативных постановлений Конституционного Совета и Верховного Суда Республики. 2) Конституция имеет высшую юриднческую силу и прямое действие на всей территории Республики. 3) Международные договоры, ратифицированные Республикой, имеют приоритет перед ее законами и применяются непосред- 
Конституция Республики Узбекистан от 8 декабря 1992 г. (ст. 17) выступает в качестве высшего императива, который находится в органической взаимосвязи с международным принципом «расta sunt servanda» - «договоры должны соблюдаться», так как государства, заключая соглашения, выступают с заявлениями о добросовестном исполнении взятых обязательств.

Конституция Узбекистана была принята в год Десятилетия международного права ООН. Это прежде всего касается положений о внешнеполитической деятельности государства, где реализуется принцип примата международного права над национальным правом. Так как действие государств вовне подпадает под регулирующее воздействие международного права, возникает взаимодействие этих правовых систем. Необходима их более тесная согласованность. Именно конституционный принцип примата международного права над национальным, если он отражается на авторитете государства, является эффективным средством обеспечения международной законности, национальной безопасности Узбекистана.

Выполнение норм международного договора «имеет место, если власти государства (т.е. само государство с международно-правовой точки зрения) хотят действовать согласно обязывающим это государство нормам международного права и внутригосударственное право им в этом не препятствует» ${ }^{14}$. Конституция Республики Узбекистан соответствует всем принципам конституционного урегулирования основ внешнеполитической деятельности государства ${ }^{15}$. Она в полной мере отражает основы современного международного права, его главственно, кроме случаев, когда из международного договора следует, что для его применения требуется издание закона. 4) Все законы, международные договоры, участником которых является Республика, публикуются. Официальное опубликование нормативных правовых актов, касающихся прав, свобод и обязанностей граждан, является обязательным условием их применения. Статья 8 Республика Казахстан уважает принципы и нормы международного права, проводит политику сотрудничества и добросовестных отношений между государствами, их равенства и невмешательства во внутренние дела друг друга, мирного разрешения международных споров, отказывается от применения первой вооруженных сил. Конституция Грузии (извлечение). Статья 6. 1) Конституция Грузии - Основной закон государства. Все другие правовые акты должны соответствовать Конституции. 2) Законодательство Грузии соответствует общепризнанным принципам и нормам международного права. Не противоречащие Конституции Грузии международные договоры или соглашения Грузия имеют преобладаюшую юридическую силу в отношении внутригосударственных нормативных актов.

14 Черниченко С.В. Международное право. Современные теоретические проблемы. М.: Междунар. отношения, 1993. С. 132. 
ные предписания. Цели и принципы внешней политики Узбекистана находятся в полном соответствии с целями и принципами международного права, служат главным образом принятию решений и созданию норм, призванных регулировать международные отношения ${ }^{16}$, в которых отсутствует надгосударственная власть.

Преамбула Конституции Республики Узбекистан определяет мирное сосуществование со всеми субъектами и соответствует ст. 1 и 2 Устава Организации Объединенных Наций 1945 г., а также содействует укреплению суверенитета своего государства ${ }^{17}$. Данное правовое положение раскрывается обеспечением территориальной целостности государства, исключающей вмешательство какого-либо государства в суверенитет Узбекистана. Юридическая природа преамбулы Основного Закона состоит в обеспечении применения на государственном уровне и соответствия основных принципов Заключительного Акта ОБСЕ 1975 г. современным аспектам международного сотрудничества государств, выраженного в правовых гарантиях.

Основой единой системы ценностей является закрепление принципов правового государства в национальных конституциях. В то же время конституция не должна препятствовать участию государства в между-

${ }^{15}$ См.: Азизходжаев A.A. Конституциявий хукук (изохли лугат). Т.: Шарк, 2001 (хаммуаллифликда); Азизходжаев $A . A$. Узбекистон Республикасининг Конституциявий хукуки. Схемали укув-методик кулланма. Т.: Шарк, 2001. (хаммуаллифликда); Азизходжаев A.A. Мустакиллик: курашлар, ихтироблар, кувончлар. - Т.: «Шарк» - «Академия", 2001.

${ }^{16}$ Международное общение есть свободный союз государств для достижения общими действиями полного развития своих сил и удовлетворения своих разумных потребностей. Совокупность юридических норм, определяющих осуществление идеи международного общения, составляет право международного общения; это есть международное право. Мартенс $Ф . \Phi$. Современное международное право цивилизованных народов. Т. 1. М.: Юридический колледж МГУ, 1996. С. 154.

${ }_{17}$ Узбекистан активно участвует в деятельности почти всех специализированных учреждений $\mathrm{OOH}$, таких как Организация Объединенных Наций по вопросам образования, науки и культуры (ЮНЕСКО), Международная организация труда (МОТ), Всемирная организация здравоохранения (ВО3), Всемирный почтовый союз (ВПС), Программа развития $\mathrm{OOH}(П Р \mathrm{OOH})$, Программа ООН по окружающей среде (ЮНЕП), Фонд оказания помощи детям (ЮНИСЕФ), Конференция ООН по торговле и развитию (ЮНКТАД), Продовольственная и сельскохозяйственная организащия ООН (ФАО), Центр ООН по населенным пунктам (ХАБИТАТ), Фонд ООН для деятельности в области народовластия (ЮНФПА), Международная организация гражданской авиацин (ИКАО), Всемирная организация интеллектуальной собственности (ВОИС) и др. См.: Комментарий к Конституции Республики Узбекистан. Т.: Адолат, 1997. С. 74.; Рахилюва М.A. ВТО и Узбекистан // Хозяйство и право. 1999. № 5. С. 77-82. 
народных договорах. Важными шагами в данном направлении являются имплементация международных обязательств и гармонизация национального правопорядка ${ }^{18}$.

Интернационализация - одна из основных тенденций современного конституционализма. Она проявляется во взаимовлиянии и сближении конституций демократических стран мира с международным правом. Достижения конституционного права отдельных стран обобщаются на международном уровне и включаются в акты международного права - пакты, конвенции, которые обязывают государства-участников внести в свое национальное законодательство те или иные демократические конституционно-правовые институты (например, определение прав человека) ${ }^{19}$.

Например, в Конституции Италии она сформулирована следующим образом: «Правопорядок Италии согласуется с общепризнанными нормами международного права» (извлечение, ст. 10 п. 1) ${ }^{20}$. Правовая природа Конституции России выражена в том, что она создает юридические гарантии реализации норм международного права. В ст. 15, п. 4. Конституции определено: «Общепризнанные принципы и нормы международного права и международные договоры Российской Федерации являются составной частью ее правовой системы. Если международным договором Российской Федерации установлены иные правила, чем предусмотренные законом, то применяются правила международного договора» ${ }^{21}$.

В Конституции ФРГ записано: «Общие нормы публичного международного права будут составной частью федерального права. Они будут обладать приоритетом перед законами и будут непосредственно создавать права и обязанности для жителей федеральной территории» (ст. 25$)^{22}$.

${ }^{18}$ Крайкемайер Анна. На пути к единой системе ценностей в рамках СБСЕ // Московский журнал международного права. 1993. № 3. С. 73.; См. также: Нъематов Ж.. Уголовно-правовые проблемы международного сотрудничества в борьбе с легализацией доходов, полученных от преступной деятельности. Автореф. дис. ... к.ю.н. Т.: Академия МВД Республики Узбекистан, 2002. С. 18: «Для эффективного международного сотрудничества в области расследования преступлений, связанных с отмыванием незаконных доходов, важное место занимает имплементация норм международного права в национальное законодательство, в целях унификации и создания единого правового пространства».

${ }^{19}$ Комментарий к Конституции Республики Узбекистан. Т.: Адолат, 1997. С. 63-64.

${ }^{20}$ Конституции мира. Сборник конституций государств мира. Т. 2. Т., 1997. С. 300.

${ }^{21}$ Конституции мира. Сборник конституций государств мира. Т. 4. Т., 1998. С. 276.

${ }^{22}$ Конституции мира. Сборник конституций государств мира. Т. 1. Т., 1997. С. 376. 
В ст. 28 П. 1 Конституции Греции 1975 г. определяется: «Общепризнанные нормы международного права, а также международные конвенции с момента их одобрения законом и вступления в действие в соответствии с их постановлениями будут составной частью внутреннего права Греции и будут превалировать над противоречащими им положениями этого права» ${ }^{23}$.

Из Конституции Франции (ст. 54 и 55) следует, что международные договоры имеют императивный характер над законами ${ }^{24}$.

Узбекистан как полноправный субъект международного права закрепляет свое равенство в международном сообществе и уважение прав, присущих суверенитету в международных отношениях со всеми субъектами, защищает независимость и территориальную целостность.

Применение принципа невмешательства во внутренние дела других государств Республикой Узбекистан показывает, что ее действия соответствуют принципам Устава $\mathrm{OOH}$, где записано, что государства обязаны воздерживаться от намерений вмешиваться в национальный суверенитет. Узбекистан строго соблюдает данный принцип, который находит свое прогрессивное развитие в сфере международного сотрудничества посредством уважения территориальной целостности и суверенитета других государств, а также в форме требования в отношении своей государственности к другим субъектам, подлежащего исполнению.

Сравнительно-правовой анализ определяет, что юридически нормы Конституции Узбекистана составляют целостное обеспечение основных принципов и норм международного права. В частности, имеется в виду принцип неприменения силы или угрозы силой, закрепленный в Уставе ООН и Заключительном Акте ОБСЕ. Данное положение на основе действующей международной практики присоединения Республики Узбекистан к международным договорам и конвенциям раскрывается с учетом правовых документов ${ }^{25}$.

${ }^{23}$ Конституции мира. Сборник конституций государств мира. Т. 2. Т., 1997. С. 23. ${ }^{24}$ Конституции мира. Сборник конституций государств мира. Т. 5. Т., 1998. С. 289. ${ }^{25}$ 1. Конвенция об улучшении участи раненых и больных в действующих армиях. Женева, 12 августа 1949 г;; 2. Конвенция об обрашении с военнопленными. Женева, 12 августа 1949 г; 3. Конвенция об улучшении участи раненых, больных и лиц, потерпевших кораблекрушение из состава вооруженных сил в море. Женева, 12 августа 1949 г.; 4. Конвенция о защите гражданского населения во время войны. Женева, 12 августа 1949 г; 5. Дополнительный протокол к Женевским конвенциям от 12 августа 1949 г., касаюшийся защиты жертв международных вооруженных конфликтов, Про- 
Основной Закон закрепил право государства определять свою правовую систему. Международное право вместе с тем установило, что при осуществлении суверенных прав, включая право устанавливать законы, государство сообразуется со своими обязательствами по международному праву. Право определять правовую систему включает и право выбирать методы обеспечения реализации международных норм на национальном уровне. Правовая природа Основного Закона состоит в том, чтобы законодательно регулировать порядок применения норм международного права в Узбекистане.

Конституция обеспечивает заключение, исполнение, прекращение, приостановление и денонсацию международных договоров государства, как двусторонних, так и многосторонних. Ст. 38 Статута Международного суда $\mathrm{OOH}$ и ст. 17 Основного Закона Республики Узбекистан юридически соответствуют друг другу и обеспечивают реализацию общепризнанных принципов и норм международного права ${ }^{26}$, находящих свою юридическую силу и применение в правовой системе государства.

Диспозитивные и императивные нормы:

А) Юридическая природа диспозитивных норм состоит в том, что государства как основные субъекты могут по взаимному соглашению отступать от соглашений;

Б) Императивная норма (jus cogens) выступает для государств как норма, которую нельзя изменить по взаимному согласию сторон, и международный договор, который не соответствует таким нормам, является юридически несостоятельным ${ }^{27}$.

токол 1. Женева, 12 августа 1949 г.; 6. Дополнительный протокол к Женевским конвенциям от 12 августа 1949 г, касающийся защиты жертв вооруженных конфликтов немеждународного характера, Протокол 2. Женева, 12 августа 1949 г;; 7. Конвенция ООН о правах ребенка. Нью-Йорк, 20 ноября 1989 г. См.: Электронно-информационная система «Гарант», Раздел «Международные документы». М., 2003.

${ }^{26}$ Со 2 марта 1992 года для Узбекистана обязательными являются принципы и нормы, содержащиеся в документах $\mathrm{OOH}$, и прежде всего в Уставе этой организации. Соответственно для республики императивными являются, кроме указанных выше пяти конституционных принципов внешней политики, также принципы: обязанности государств сотрудничать друг с другом; равноправия и самоопределения народов; добросовестного выполнения обязательств по международному праву; территориальной целостности государства; уважения прав и основных свобод человека. Турсунов А.С. Конституционные основы внешней политики Республики Узбекистан. Автореферат дис. ... д-ра юрид. наук. Т.: АГОС, 2002. С. 25.

${ }^{27} C_{M}$.: Rohn P. Указ. соч. 
Сравнительно-правовой анализ развития правовой системы Республики Узбекистан отражен в ст. 3 Закона Республики Узбекистан «О международных договорах Республики Узбекистан» от 22 декабря 1995 г. «Понятие международного договора»: Международный договор Республики Узбекистан - это равноправное и добровольное соглашение республики с одним или несколькими государствами, международными организациями или с другими субъектами международного права относительно прав и обязанностей в области международных отношений.

В целом привнесение в национальное право консолидированного мирового юридического опыта становится ведущей тенденцией правового развития ${ }^{28}$. Конкретное содержание президентской власти определено Конституцией. Согласно Конституции Президент Республики Узбекистан выполняет основную функцию в деле обеспечения международного сотрудничества государства на мировой арене. Особо важное значение имеет обеспечение выполнения принятых обязательств Республикой Узбекистан по международным договорам, что входит в компетенцию Президента Республики.

Для сравнения отметим: Конституция США от 17 сентября 1787 г. в п. 2 отд. 2 ст. 2 определяет, что Президент страны имеет право совета и согласия Сената заключать договоры, если согласие дают 2/3 присутствующих сенаторов. Эта же Конституция в п.п. 1 и 3 отд. 10 ст. 1 устанавливает, что ни один штат не может вступать в договоры, союзы или конфедерации и без согласия Конгресса заключать соглашения или конвенции с другим штатом или с иностранной державой ${ }^{29}$.

Президент Узбекистана на основании Основного Закона, который наделяет его широтой международных полномочий, принимает необходимые меры для того, чтобы международное сотрудничество государства с друтими субъектами находило все более эффективное применение на основании примата норм международного права и последующей имплементации этих норм и принципов в национальном праве.

Все ранее сказанное позволяет сделать вывод о том, что Президент Узбекистана определяет долгосрочные политико-правовые основы для осуществления договорно-правовых обязательств, характер взаимодействия страны с субъектами. Активизируется участие правовой систе-

\footnotetext{
${ }_{2 *}^{2 *}$ С..: Саидов А.Х. Сравнительное правоведение. Т.: Адолат, 1999. С. 466-476.

${ }^{29}$ См.: Дирденевский B.H. Московский журнал международного права. № 1 (37), 2000. C. 65 .
} 
мы Узбекистана в процессе глобализации внутреннего права государств и интернационализации ${ }^{30}$, доместикации ${ }^{31}$ международного права. В результате достигается более высокий уровень цивилизованности правового регулирования в стране и повышается эффективность международного права.

Конституция обеспечивает порядок заключения международных договоров, соответствующих системе международного права, и соответствует Венской конвенции о праве международных договоров $1969 r_{.}^{32}$ Национальная норма обеспечивает право на участие всех субъектов на стадиях заключения международных договоров. Это важное условие прогрессивного развития международного права, которое в свою очередь, основано на уважении правовых систем государств. Конституция предусматривает, как и нормы международного права (jus cogens), единообразное применение правил процедур, используемых на стадиях международного правотворчества.

Суверенное равенство государств при заключении договоров - это взаимное уважение суверенитета государствами (субъектами), что основывается на равенстве при осуществлении правоспособности и дееспособности на стадиях заключения договоров. Суверенитет является основным принципом международного права, который органически взаимосвязан с правом международных договоров.

«В области международных отношений суверенитет не имеет того объема, как в государственном управлении. Различие немедленно обнаруживается, как только государство вступит в сношения с другими народами и пожелает заключать с ними обязательства и пользоваться международными правами: тогда силою вещей оно вынуждено будет делать уступки, уважать законные интересы и права других народов, должно отказаться от безусловного осуществления своего верховенства. Абсолютное, в смысле государственного права, начало суверенитета определяется в международном общении взаимными отношениями, которые существуют между народами и ими ограничиваются» ${ }^{33}$.

${ }^{30}$ Internationalize (aнz.) - делать интернациональным; ставить под контроль различных государств. Сл.: Мюллер B.К. Англо-русский словарь. 23-е изд. М.: Русский язык, 1992. C. 374.

${ }^{31}$ Domestic (анг.) - внутренний; отечественный. См.: Мюллер В.К. Англо-русский словарь. 23-е изд. М.: Русский язык, 1992. С. 217.

${ }^{32}$ Такими стадиями согласно Венской конвенции о праве международных договоров 1969 г. Являются: 1) принятие текста международного договора, 2) установление аутентичности текста, 3) выражение согласия на юридическую обязательность международного договора (ратификация, подписание, прннятие, утверждение, присоединение). 
Независимость государства от какого-либо субъекта проявляется в праве государства свободно, по собственному усмотрению заключать соглашения, без вмешательства в дела другого субъекта и без нарушения общепризнанных принципов и норм международного права.

По Венской конвенции о праве международных договоров 1969 г. (ст. 27) внутреннее право и соблюдение договоров Республика Узбекистан обязана обеспечить в процессе выполнения международных договоров ${ }^{34}$. Она выступает как международный гарант (de-jure), без ущерба для этой статьи, основываясь на международном принципе «расta sunt servanda» - ст. 26 Венской конвенции о праве международных договоров 1969 г. Основной Закон воплотил в себе принцип добросовестного выполнения международных договоров, который принадлежит к числу тех принципов, без которых невозможно нормальное функционирование современного международного права. Выяснение юридической природы Конституции, в том числе статей, имеюших прямое отношение к международному праву, способствует развитию теоретического мышления, углублению процесса познания правовой действительности. При этом важно оценивать роль Олий Мажлиса Республики Узбекистан, который является высшим государственным органом, осуществляющим законодательную власть.

${ }^{33}$ Мартенс $\Phi . \Phi$. Современное международное право цивилизованных народов. Т. 1. М.: Юридический колледж МГУ, 1996. С. 196.

${ }^{34}$ Поставлена проблема приоритетности общепризнанных норм международного права в Конституции Республики Узбекистан. Суть проблемы заключается в определенном противоречии между законодательным определением вопроса о юридической силе Преамбулы и характером выраженного в Преамбуле принципа приоритета обшепризнанных норм международного права, адресованного законодателю и обладаюшего свойством юридической нормы-принципа. Отсюда вытекают другие проблемы, в том числе определения порядка практической реализации примата норм международного права, а также правил разрешения коллизий между нормой международного права и Конституцией и др. В этой связи рекомендуется из Преамбулы перенести данный принцип в III главу Конституции, а также указать, что если международным договором Республики Узбекистан установлены иные правила, чем предусмотренные законодательством Республики Узбекистан, то напрямую применяются правила международного договора. Таюже рекомендуется законодательно определить правила имплементации. Конкретный порядок трансформации или инкорпорации норм международного права в национальное законодательство. См.: Турсунов А.С. Конституционные основы внешней политики Республики Узбекистан. Автореферат дис. ... д-ра юрид. наук. Т:: Академия Государственного и общественного строительства при Президенте Республики Узбекистан, 2002. С. 12. 
В соответствии с Конституцией Олий Мажлис осуществляет законодательное оформление международных договоров, парламентский контроль за деятельностью исполнительной власти, внешнеполитических ведомств и их руководителей путем обсуждения принципов и норм международного права, практики их применения в национальном законодательстве.

Конституционное закрепление принципа примата международного права над национальным правом позволяет решать вопросы применения международного договора и приведения норм национального права в соответствие с нормами международных договоров. Если такие действия необходимы, то они выполняются законодательным органом страны - Олий Мажлисом. Конституционное регулирование примата международного права над национальным выступает в качестве высшей юридической нормы осуществления государством его внешнеполитических прерогатив. Тем самым государство выполняет основные свои внешние функции по регламентированию международных и национальных (государственных) отношений. Такая существенно важная функция - функция правового регулирования - для него является юридически обязательной.

Конституционные принципы внешней политики Республики Узбекистан, как и вообще принципы и нормы национального права и принципы международного права, обладают рядом общих черт. В частности, и те, и другие имеют юридически обязательный характер. Кроме того, две правовые системы теоретически представлены одним общим субъектом - государством, которое в своей внешнеполитической деятельности применяет как конституционные принципы, так и принципы международного права.

Роль Конституции в национальном праве республики состоит в формировании и развитии международных принципов, которые могут выступать в качестве средств установления новых норм международного права. Обращаем внимание и на принцип общеобязательности юридической силы Конституции и международного договора, так как стороны, составляя соглашения, заявляют о добросовестном исполнении взятых обязательств (ст. 17 Конституции).

Носители прав и обязанностей в национальном законодательстве, источником которого является международный договор, самостоятельно не могут определить пути и способы выполнения (исполнения) этих норм, а обязаны строго следовать их юридически обязательной силе и 
нормам Конституции. Деятельность субъектов национального права по реализации норм международного права представляет собой опосредованную правом совокупность организационно-оперативных мер, как правило, не связанных с процессом правотворчества. Дополнительные правотворческие мероприятия, направленные на выполнение норм международного права, имеют место при реализации норм права только властными органами государства.

Особенностью конституционной гарантии является принцип добросовестного выполнения обязательств, вытекающих из общепризнанных принципов и норм международного права и из заключенных Узбекистаном международных договоров. Нормативное закрепление этого принципа в Основном Законе выражает полную приверженность как действующим общепризнанным принципам и нормам международного права, а также готовность строго и неуклонно выполнять обязательства, принятые в соответствии с заключенными международными договорами. Став внутригосударственной нормой, эти принципы приобретают качество главной национально-правовой гарантии примата норм международного права. 